\title{
Familial Breast Cancer, Prevention, Risk Factors and Genetics - Highlights from the San Antonio Breast Cancer Symposium (SABCS) Poster Presentations
}

\author{
Dirk Olaf Bauerschlag Christian Schem Christoph Mundhenke Ivo Meinhold-Heerlein \\ Walter Jonat Nicolai Maass
}

Klinik für Gynäkologie und Geburtshilfe, Universitätsklinikum Schleswig Holstein, Campus Kiel, Germany

\section{Key Words}

Breast cancer, familial · Prevention - Genetics

\section{Summary}

This article summarizes the contents of posters which were presented at the San Antonio Breast Cancer Symposium in sessions dealing with familial breast cancer, prevention, risk factors and genetics. Genetic testing for inherited or high-risk breast cancer was one of the main topics, focusing on the genetic counseling in women with hereditary breast cancer from different social and ethnic backgrounds. Information and training in breast self-awareness are important factors for reducing cancer anxiety. In mice, chemoprevention in breast cancer using retinoids showed to be effective by reducing tumor multiplicity. Vitamin A derivatives and COX 2 inhibitors could be potentially used to prevent breast cancer in woman at increased risk. Inhibition of EGFR (epidermal growth factor receptor) kinase reduces tumor multiplicity and could re-sensitize tumors to taxane chemotherapy. Analysis of histological subtypes of breast cancer demonstrated differences in DNA methylation and molecular marker expression. Lifestyle, e.g. oral contraception or hormone replacement therapy, is affecting patients at both basic and high risk of developing breast cancer.

\author{
Schlüsselwörter \\ Brustkrebs, familiärer · Prävention · Genetik
}

\section{Zusammenfassung}

Dieser Artikel fasst Inhalte von Postern zusammen, die zu den Themen familiärer Brustkrebs, Prävention, Risikofaktoren und genetische Grundlagen auf dem San Antonio Breast Cancer Symposium präsentiert wurden. Einer der Schwerpunkte war die genetische Testung bei Patientinnen mit erblichem Brustkrebs oder mit hohem Brustkrebsrisiko. Insbesondere wurde die genetische Beratung bei Patientinnen mit erblichen Brustkrebs oder hohem Brustkrebsrisiko vor dem Hintergrund sozialer und ethnischer Unterschiede untersucht. Die Einführung von Kursen zur Selbstuntersuchung der Brust und die leichte Zugänglichkeit von Informationen reduziert deutlich die krebsbezogene Angst. Retinoide führen im Mausmodell zu einer effektiven Reduktion der Tumormultiplizität. Vitamin-A-Derivate oder COX-2-Inhibitoren können potentiell zur medikamentösen Prävention von Brustkrebs bei Patientinnen mit erhöhtem Brustkrebsrisiko eingesetzt werden. Hemmung der EGFR (epidermal growth fator receptor)-Kinase führt zu einer Reduzierung der Tumormultiplizität. Weiter könnte diese Hemmung zur einer Resensitivierung von Mammakarzinomen für taxanhaltige Chemotherapie führen. Histologische Subtypen beim Mammakarzinom zeigen Unterschiede hinsichtlich der DNA-Methylierung und der Expression von molekularen Markern. Der Lebensstil, z.B. das Einnehmen hormoneller Kontrazeptiva oder die Hormonersatztherapie, können sowohl die Inzidenz als auch den Krankheitsverlauf bei Patientinnen mit normalem oder erhöhtem Brustkrebsrisiko beeinflussen.

\begin{tabular}{ll}
\hline KARGER & ( 2006 S. Karger GmbH, Freiburg \\
Fax +49 7614520714 & Accessible online at: \\
$\begin{array}{l}\text { E-mail Information@Karger.de } \\
\text { www.karger.com }\end{array}$ & www.karger.com/brc
\end{tabular}




\section{Familial Breast Cancer}

Genetic testing for hereditary breast cancer or in patients at high risk of developing breast cancer was a topic that was approached from different angles at this San Antonio Breast Cancer Symposium (SABCS). In Germany, genetic counseling and testing is available in 12 university centers. An interdisciplinary team of geneticists, gynecologists and psychologists is involved in the counseling process and is providing expert opinions on intensified surveillance programs and breast cancer prevention (e.g. chemoprevention or prophylactic surgery) [1]. Since the summer of 2005, the genetic counseling program composed of genetic testing, interdisciplinary counseling and clinical prevention program is included in the benefits of many German health insurance companies. The service is utilized by referral or is directly approached by motivated and informed women.

The counseling is organized differently in other countries. One special focus of the SABCS was on the access to such programs by underserved women [2] - often lacking health insurance coverage - or women of different ethnic backgrounds [3]. Women were more often actively recruited for such programs, since a lack of information often is a reason for not participating. Recruiting patients actively did not cause any additional short-term psychological burden [4]. Among underserved women in the US, the offered genetic counseling was well accepted. In a small cohort of such women, Reyes et al. [5] reported more BRCA 2 mutations. With respect to family history, this cohort was not very well characterized. However, despite the limited number of patients in this study; ethnic background might be a factor worth considering in genetic counseling.

Mutations in the CHEK2 gene (CHEK2*1000delC) were not significantly different when a population-based cohort $(0.9 \%)$ was compared to a clinic-based breast cancer cohort $(0.8 \%)$. However, within the subgroup of patients with early-onset breast cancer this mutation was found at a frequency of $2.3 \%$ referring to an increased breast cancer risk of 2.6. In patients with familial breast cancer tested negative for BRCA1 and BRCA2 mutations, CHEK2*1000delC mutations were found at a frequency of $1.4 \%$, constituting an increased breast cancer risk of 1.5 [6]. The CHEK2 gene is of low penetrance and does not seem to play a pivotal role in hereditary breast cancer [7].

\section{Prevention}

Prevention is still one of the pitfalls in breast cancer therapy. So far, no surrogate marker (i.e. serum marker) has been established for routine use. Even in high-risk breast cancer families genetic testing cannot provide definite certainty. Therefore, different prevention strategies should be offered to patients of normal or high breast cancer risk: i) breast selfawareness programs, ii) mammography screening programs, iii) chemoprevention and iv) prophylactic operations, such as prophylactic skin sparing mastectomy or bilateral salpingooophorectomy (BSO). By introducing breast self-examination courses and general information, the level of breast cancer worries and anxiety as one of the reasons for turning down screening offers could be reduced [8]. Offering invasive prophylactic procedures must be based on acceptance levels. More than $70 \%$ of patients (mutation carriers or high-risk family history) decided to take part in intensified surveillance programs rather than in preventive surgery $[2,9]$. Intensified surveillance programs are also available for patients counseled within the German working group of 'Konsortium familiärer Brust- und Eierstockkrebs'. This program includes breast examination, ultrasound (biannually), mammography and magnetic resonance imaging (annually). It is mandatory that all examinations are conducted in one of the specialized centers to warrant continuous and standardized follow-up examinations. Surgical prevention strategies reduce the risk by $>98 \%$ in the case of prophylactic mastectomy [10, 11]. BSO reduced the breast cancer risk by $50 \%$ when performed before the age of 40 [12-14]. Despite this enormous risk reduction, the vast majority of patients at high risk of breast cancer did prefer the intensified breast cancer surveillance program. Prophylactic mastectomy was accepted by as few as $16 \%$ of the high-risk patients before the age of 35 [15].

Chemoprevention by anti-hormonal therapy outlines another strategy in breast cancer prevention. But since most of BRCA 1 mutation carriers develop non-hormone-sensitive breast cancer, this approach is under constant debate. The mean age of patients developing hereditary breast cancer is 20 years younger than with sporadic breast cancer. In this premenopausal setting, the selective estrogen receptor modulator tamoxifen is currently the only valid option. New approaches are combinations of low-dose tamoxifen ( $5 \mathrm{mg}$ /day) and a vitamin A derivative, which have been shown to have a potential benefit [16] in premenopausal women at increased risk of breast cancer. However, the unusual tamoxifen dosage used might be one of the reasons that there was no synergistic effect. Preventing secondary breast cancer using the vitamin A analogue fenretinide showed a potential effect in premenopausal women [17]. One well recruiting ongoing study is the IBIS II study, in which postmenopausal women at moderate or high risk of breast cancer receive anastrozole or placebo. Patients with a histologically confirmed ductal carcinoma in situ (DCIS) receive tamoxifen $20 \mathrm{mg}$ or anastrozole.

Several poster presentations contained data relating to breast cancer prevention efficacy of different drugs in methylnitrosourea (MNU)-induced rat models. Retinoid $\mathrm{X}$ receptor (RXR)-specific retinoids decreased cancer multiplicity by up to $85 \%$ [18]. Similar results were demonstrated by Lubet et al. [19] regarding the RXR agonist targretin. Combinations of atorvastatin or lovastatins with RXR agonists or suboptimally dosed tamoxifen did not show a synergistic effect. Vitamin A 
analogues seemed to regulate cell cycle progression by inhibiting cyclin D1 and D3 [20], differentiation and apoptosis [21, 22]. Nuclear retinoic receptors, such as the retinoid acid receptor (RAR) or RXR are ligand-activated transcription factors. Heterodimers of RAR and RXR bind to retinoic acid responsive elements (RARE) which in turn activate transcription factors [23]. Vitamin A derivatives might be of potential benefit but also have toxic side effects, such as hyperlipidemia, mucocutaneous toxicity and liver toxicity.

The EGFR inhibitor gefitinib showed a marked reduction in tumor multiplicity by $88 \%$ [24]. Although the EGFR signaling pathway seemed to be a promising target in cancer therapy, gefitinib did not however show any advantage in treating nonsmall cell lunge cancer (FDA alert 6/2005). Inhibition of EGFR tyrosine kinase could reverse drug resistance by directly inhibiting phosphoglycolate phosphatase [25]. This could resensitize cancers to taxane therapy.

It is tempting to introduce cyclooxygenase 2 inhibitors with known anti-angiogenic [26], anti-proliferative and apoptotic [27] capacity into breast cancer prevention in women at increased risk. The investigation of surrogate markers for proliferation, such as the Ki-67 and ER expression level, in women at increased risk of breast cancer showed that celecoxib changed the level of ER expression significantly but did not have a significant influence on the Ki-67 level [28]. Inhibition of cyclooxygenase 2 reduced the aromatase activity in a dosedependent manner [29]. COX 2 levels were also downregulated by retinoids, such as LGD 1069, which also decreased levels of cyclin D1 in human mammary epithelial cells [30].

\section{Genetics}

Although breast cancer is the most common malignancy in women in the Western world, the research community has not yet found a well accepted molecular surrogate marker for neither the detection of breast cancer nor the prediction of disease-free survival and overall survival. Genetic profiling is one of the approaches several groups have used to identify genetic fingerprints [31]. However, with these new techniques criticism is never far away, focusing on the fact that results are not consistently reproducible [32]. Another pitfall with genetic analysis is that findings at the transcriptional level do not always correlate with the protein level. But still, genetic analysis is one of the most powerful research tools. Comparing invasive lobular carcinoma and the high-grade pleomorphic variant did show that histomorphological differences were not always reflected by molecular characterization. Both entities seem to rely on genetic alteration on chromosomes 1q and 16q. Analyzed by comparative genomic hybridization, both variants had more gains than losses, and both were negative for E-cadherin [33]. The histological subtype of lobular breast cancer was also negative for p53 and HER-2 expression, but cyclin D1 was amplified promoting proliferation by regulating the cell cycle in the G1 phase $[34,35]$. Polymorphism regarding this key regulator showed a difference in metastasis-free survival. A cyclin D1 $870 \mathrm{G}>\mathrm{A}$ polymorphism was associated with a longer metastasis-free survival, although this polymorphism seems to correlate with hormone-insensitive breast cancers known to be clinically more aggressive [36]. Looking at different histological subtypes of breast cancer using the single nucleotide polymorphism (SNP) technique, the mean copy number in invasive ductal breast cancers was significantly different form invasive lobular breast cancers. By clustering tumors according to significantly different SNPs, a clear line of demarcation between the histological subtypes could be drawn. Within these clusters, SNPs located nearby genes encoding hormone response, cell adhesion or tumor suppression were identified. These results support the use of genetic analysis in differentiating tumor subtypes in order to find potential molecular targets [37].

DNA hypermethylation is a common step in carcinogenesis. It seems to occur in the early stages of breast cancer development. Hypermethylation of tumor suppressor genes, such as cyclin D 2 and RAR $\beta 2$, were more frequent in DCIS than in invasive breast cancer [38]. BRCA1 methylation was correlated with fewer transcripts. Promoter hypermethylation occurred more frequently in younger women, high-grade and hormone receptor-negative tumors [39].

\section{Risk Factors}

Lifestyle might be one factor that affects normal and high-risk groups equally. Hormonal treatment raises the question of increased breast cancer risk. Premenopausal women that used hormonal contraceptives prior to their breast cancer diagnosis do not have a worse prognosis. The fact that breast cancer is diagnosed earlier in patients using oral contraceptives is probably related to the more frequent visits to the doctor to get a prescription than to the effects of the pill. [40]. There is also an ongoing debate about the influence of hormone replacement therapy (HRT) on breast cancer risk [41, 42]. The Million Women Study [43] showed an increased risk of breast cancer in women using estrogen only. The risk was even more increased in women using a combination of estrogen and progesterone as HRT. Against the background of this study, investigations of molecular changes in breast tissue during HRT may give insights into the development of breast cancer. Using a pre- and post-treatment core biopsy of the breast after 6 months of combined estrogen-progestin HRT, no differences could be observed in the proliferation index assessed by Ki-67 staining. There was also no difference in the expression of estrogen or progesterone receptors, and HRT did not seem to have a positive influence on angiogenesis measured by CD 34 expression [44]. Further investigations are needed to find the molecular basis for increased breast cancer risk in women using HRT. 


\section{References}

1 Schmutzler R, Schlegelberger B, Meindl A, Gerber WD, Kiechle M: Counselling, genetic testing and prevention in women with hereditary breast- and ovarian cancer. Interdisciplinary recommendations of the consortium 'Hereditary Breast- and Ovarian Cancer' of the German Cancer AiD. Zentralbl Gynakol 2003:125:494-506.

2 Beattie MS, Lee RF, Crawford B et al.: Genetic counseling and testing for hereditary breast cancer in underserved women. Breast Cancer Res Treat 2005;94(suppl 1):abstr 4001

3 Fowler ES, Neese ER, Schwartzberg LS et al.: Determinants in the uptake of genetic testing for BRCA1/2 mutations. Breast Cancer Res Treat 2005;94(suppl 1):abstr 4005.

4 Warlam-Rodenhuis CC, Schlich-Bakker KJ, van Echtelt et al.: Actively approaching breast cancer patients for genetic counselling during adjuvant radiotherapy: does it harm? Breast Cancer Res Treat 2005;94(suppl 1):abstr 4003.

5 Reyes JM, Jara L, Bustamante E et al.: BRCA 1 and BRCA 2 mutations in a South American population. Breast Cancer Res Treat 2005;94(suppl 1): abstr 4010.

6 Hamann U, Rashid MU, Jakubowska A et al.: German populations with infrequent CHEK2*1000 delC and minor association with early onset and familial breast cancer. Breast Cancer Res Treat 2005; 94(suppl 1):abstr 4002

7 Dufault MR, Betz B, Wappenschmidt B, Hofmann W, Bandick K, Golla A, Pietschmann A, NestleKramling C, Rhiem K, Huttner C, von Lindern C, Dall P, Kiechle M, Untch M, Jonat W, Meindl A Scherneck S, Niederacher D, Schmutzler RK, Arnold N: Limited relevance of the CHEK2 gene in hereditary breast cancer. Int J Cancer 2004;110: 320-325.

8 Artmann A, Heyne M, Ruessmann B et al: Counseling and care combined with breast self examination training as motivation strategy for breast cancer awareness and participation in breast cancer screening programs. Breast Cancer Res Treat 2005; 94(suppl 1): abstr 4028.

9 Kurian AW, Hartmann AR, Mills MA et al.: Breast cancer risk management choices by women with inherited breast cancer predisposition: a preliminary analysis. Breast Cancer Res Treat 2005;94(suppl 1): abstr 4006 .

10 Meijers-Heijboer H, van Geel B, van Putten WL, Henzen-Logmans SC, Seynaeve C, MenkePluymers MB, Bartels CC, Verhoog LC, van den Ouweland AM, Niermeijer MF, Brekelmans CT, Klijn JG: Breast cancer after prophylactic bilateral mastectomy in women with a BRCA1 or BRCA2 mutation. N Engl J Med 2001;345:159-164.

-11 Hartmann LC, Schaid DJ, Woods JE, Crotty TP Myers JL, Arnold PG, Petty PM, Sellers TA, Johnson JL, McDonnell SK, Frost MH, Jenkins RB: Efficacy of bilateral prophylactic mastectomy in women with a family history of breast cancer. N Engl J Med 1999;340:77-84.

12 Kauff ND, Satagopan JM, Robson ME, Scheuer L, Hensley M, Hudis CA, Ellis NA, Boyd J, Borgen PI, Barakat RR, Norton L, Castiel M, Nafa K, Offit $\mathrm{K}$ : Risk-reducing salpingo-oophorectomy in women with a BRCA1 or BRCA2 mutation. N Engl J Med 2002;346:1609-1615.

13 Rebbeck TR, Lynch HT, Neuhausen SL, Narod SA, Van't Veer L, Garber JE, Evans G, Isaacs C, Daly MB, Matloff E, Olopade OI, Weber BL: Prophylactic oophorectomy in carriers of BRCA1 or BRCA2 mutations. N Engl J Med 2002;346: 1616-1622.

14 Rebbeck TR, Levin AM, Eisen A, Snyder C, Watson $\mathrm{P}$, Cannon-Albright L, Isaacs $\mathrm{C}$, Olopade $\mathrm{O}$, Garber JE, Godwin AK, Daly MB, Narod SA, Neuhausen SL, Lynch HT, Weber BL: Breast cancer risk after bilateral prophylactic oophorectomy in BRCA1 mutation carriers. J Natl Cancer Inst 1999;91:1475-1479.
5 Julian-Reynier CM, Bouchard LJ, Evans DG, Eisinger FA, Foulkes WD, Kerr B, Blancquaert IR, Moatti JP, Sobol HH: Women's attitudes toward preventive strategies for hereditary breast or ovarian carcinoma differ from one country to another: differences among English, French, and Canadian women. Cancer 2001;92:959-968.

16 Veronesi U, De Palo G, Marubini E, Costa A Formelli F, Mariani L, Decensi A, Camerini T, Del Turco MR, Di Mauro MG, Muraca MG, Del Vecchio M, Pinto C, D'Aiuto G, Boni C, Campa T, Magni A, Miceli R, Perloff M, Malone WF, Sporn MB: Randomized trial of fenretinide to prevent second breast malignancy in women with early breast cancer. J Natl Cancer Inst 1999;91: 1847-1856.

17 Bonanni B, Guerrieri-Gonzaga A, Robertson C et al.: Preliminary results of a randomized phase IIb study double-blind $2 \times 2$ trial of low dose tamoxifen and fenretinide for breast cancer prevention. Breast Cancer Res Treat 2005;94(suppl 1):abstr 4012.

18 Christov K, Muccio D, Brouillette W et al.: Chemoprevetive efficacy of new RXR specific retinoids against mammary cancers and correlation with short-term biomarkers. Breast Cancer Res Treat 2005;94(suppl 1):abstr 4014.

19 Lubet R, Grubbs C, Steele V et al: Chemopreventive effects of the statins, liptor and lovastatin, in the methylnitrosourea (MNU) - induced model of mammary carcinogenesis. Breast Cancer Res Treat 2005;94(suppl 1):abstr 4019

20 Zhou Q, Stetler-Stevenson M, Steeg PS: Inhibition of cyclin D expression in human breast carcinoma cells by retinoids in vitro. Oncogene 1997;15: 107-115

21 Wu K, Dupre E, Kim H, Tin UC, Bissonnette RP, Lamph WW, Brown PH: Receptor-selective retinoids inhibit the growth of normal and malignant breast cells by inducing G1 cell cycle blockade. Breast Cancer Res Treat 2005:1-11.

22 Barna G, Sebestyen A, Weischede S, Petak I, Mihalik R, Formelli F, Kopper L: Different ways to in duce apoptosis by fenretinide and all-trans-retinoic acid in human B lymphoma cells. Anticancer Res 2005;25:4179-4185.

23 Simeone AM, Tari AM: How retinoids regulate breast cancer cell proliferation and apoptosis. Cell Mol Life Sci 2004;61:1475-1484.

24 Grubbs C, Christov K, You M et al.: Chemopreven tive effects of the EGFR inhibitor Iressa in th methylnitrosourea (MNU) - induced model of mammary carcinogensis. Breast Cancer Res Treat 2005;94(suppl 1):abstr 4017

25 Kitazaki T, Oka M, Nakamura Y, Tsurutani J, Doi S, Yasunaga M, Takemura M, Yabuuchi H, Soda H, Kohno S: Gefitinib, an EGFR tyrosine kinase inhibitor, directly inhibits the function of P-glycoprotein in multidrug resistant cancer cells. Lung Cancer 2005;49:337-343.

26 Wu G, Luo J, Rana JS, Laham R, Sellke FW, Li J: Involvement of COX-2 in VEGF-induced angiogenesis via P38 and JNK pathways in vascular endothelial cells. Cardiovasc Res 2006;69:512-519.

27 Ferrandina G, Ranelletti FO, Legge F, Lauriola L, Salutari V, Gessi M, Testa AC, Werner U, Navarra P, Tringali G, Battaglia A, Scambia G: Celecoxib modulates the expression of cyclooxygenase-2, ki67, apoptosis-related marker, and microvessel density in human cervical cancer: a pilot study. Clin Cancer Res 2003;9:4324-4331.

28 Arun B, Valero V, Hornbeak J et al: Celecoxib down regulates estrogen receptor expression in breast tissue of women at increased risk for developing breast cancer. Breast Cancer Res Treat 2005;94(suppl 1):abstr 4013.
Brueggemeier RW, Diaz-Cruz ES, Li PK, Sugimoto Y, Lin YC, Shapiro CL: Translational studies on aromatase, cyclooxygenases, and enzyme inhibitors in breast cancer. J Steroid Biochem Mol Biol 2005;95:129-136.

$30 \mathrm{Li}$ Y, Kim H, Uray I et al.: Identification of genes modulated by LGD 1069, a retinoid that prevents mammary tumorgenesis. Breast Cancer Res Treat 2005;94(suppl 1):abstr 4024

31 Van't Veer LJ, Dai H, van de Vijver MJ, He YD, Hart AA, Mao M, Peterse HL, van der Kooy K, Marton MJ, Witteveen AT, Schreiber GJ, Kerkhoven RM, Roberts C, Linsley PS, Bernards R, Friend SH: Gene expression profiling predicts clinical outcome of breast cancer. Nature 2002;415: 530-536.

32 Michiels S, Koscielny S, Hill C: Prediction of cancer outcome with microarrays: a multiple random validation strategy. Lancet 2005;365:488-492.

33 Simpson P, Reis-Filho J, Mackay A et al.: Invasive lobular carcinoma and the high grade variant pleomorphic lobular carcinoma: molecular characterization. Breast Cancer Res Treat 2005;94(suppl 1): abstr 1106.

34 Grillo M, Bott MJ, Khandke N, McGinnis JP, Miranda M, Meyyappan M, Rosfjord EC, Rabindran SK: Validation of cyclin D1/CDK4 as an anticancer drug target in MCF-7 breast cancer cells: effect of regulated overexpression of cyclin D1 and siRNAmediated inhibition of endogenous cyclin D1 and CDK4 expression. Breast Cancer Res Treat 2006; 95:185-194.

35 Reis-Filho JS, Simpson PT, Lambros M et al.: Classic lobular breast carcinoma: comprehensive molecular genetic analysis. Breast Cancer Res Treat 2005; 94(suppl 1):abstr 1107.

36 Hofmann G, Langenslehner U, Renner W et al. Breast cancer metastasis free survival and its association to a common hereditary gene polymor phism of cyclin D1. Breast Cancer Res Treat 2005;94(suppl 1):abstr 1112.

37 Ton CC, Loo LW, Grove DI et al.: SNP microarray analysis of genomic alterations in infiltrating ducta carcinoma and infiltrating lobular carcinoma 1 . Breast Cancer Res Treat 2005;94(suppl 1):abstr 1109.

38 Sullivan RF, Kim SJ, Zapparoli GV et al.: Is aberrant hypermethylation an early event in breast cancer? Breast Cancer Res Treat 2005;94(suppl 1): abstr 1108 .

39 Wei M, Grushko TA, Dignam J, Hagos F, Nanda R, Sveen L, Xu J, Fackenthal J, Tretiakova M, Das S, Olopade OI: BRCA1 promoter methylation in sporadic breast cancer is associated with reduced BRCA1 copy number and chromosome 17 aneusomy. Cancer Res 2005;65:10692-10699.

40 Clarke E, Haji A, Kalimuddin S et al.: The effect of the oral contraceptive pill on prognosis and survival in women with breast cancer. Breast Cancer Res Treat 2005;94(suppl 1):abstr 6015.

41 Nelson HD, Humphrey LL, Nygren P, Teutsch SM Allan JD: Postmenopausal hormone replacement therapy: scientific review. Jama 2002;288:872-881.

42 Breast cancer and hormone replacement therapy: collaborative reanalysis of data from 51 epidemiological studies of 52,705 women with breast cancer and 108,411 women without breast cancer. Collaborative Group on Hormonal Factors in Breast Cancer. Lancet 1997:350:1047-1059.

43 Beral V: Breast cancer and hormone-replacemen therapy in the Million Women Study. Lancet 2003; 362:419-427.

44 Elias S, Dardes RC, Baracat EC et al.: Morphological and immunohistochemical aspects of the breast tissue in postmenopausal women before and after hormone replacement therapy. Breast Cancer Res Treat2005;94(suppl 1):abstr 6012. 